\title{
Resource Adequacy and Utilization for Teaching and Learning Effectiveness in Vocational Education Programmes in South-South Nigerian Universities
}

\author{
James Edomwonyi Edokpolor ${ }^{*}$, David Nwanna Dumbiri ${ }^{2}$ \\ ${ }^{1}$ Benson Idahosa University, P.M.B. 1100, Benin City, Edo State, Nigeria \\ ${ }^{2}$ University of Benin, P.O. Box 1154, Benin City, Edo State, Nigeria \\ *Corresponding author, e-mail: jedokpolor@biu.edu.ng
}

\begin{abstract}
This study investigated the level of physical facilities adequacy and instructional resources utilization for teaching and learning effectiveness in Technical and Vocational Education and Training (TVET) programmes. A quantitative research design was used, with a sample of 700 participants (85 lecturers and 615 students) which was randomly selected across three Federal Universities in SouthSouth, Nigeria. Structured questionnaires were used to collect data from TVET lecturers and students. Mean, standard deviation and t-test were used for data analyses. Physical facilities were found to be inadequate for teaching and learning processes in TVET programmes. Also, instructional resources were found to be underutilized during teaching and learning in TVET programmes. One of the recommendations made for the study is that TVET managers should endeavour to collaborate with major stakeholders for the provision of funds that would assist in ensuring adequate provision of physical facilities for effective teaching and learning processes in TVET programmes. As such, this would further help to foster the conducive environment for teaching and learning of TVET courses, which in turn, would help in equipping students with the skills to pursue entrepreneurial careers and lifelong learning upon graduation.
\end{abstract}

Keywords: Instructional resources utilization, Lecturers and students, Physical facilities adequacy, Teaching and learning effectiveness, Technical and vocational education and training.

\section{INTRODUCTION}

The realization of the United Nation's 2030 agenda for Sustainable Development Goals (SDGs) in Nigeria is hinged on the implementation of Technical and Vocational Education and Training (TVET) through resource adequacy and utilization and teaching and learning effectiveness. The United Nations (2017) stated that Goal 4 aimed to ensure that every individual have equal access to quality education and training and opportunity for lifelong learning. It stipulated that the Goal goes beyond school enrolment and looks at proficiency levels, availability of trained teachers and the provision of school facilities and disparities in education outcomes. Similarly, the Federal Republic of Nigeria (FRN, 2017) in its sustainable development document stated that Goal 4 of the agenda shall be achieved through the "...acquisition of foundational and higher-order skills; greater and more equitable access to technical and vocational education and training and higher education; training throughout life; and the knowledge, skills and values needed to function well and contribute to society" (p. 4). The FRN (2004) in its education policy document captures the role of TVET to its recipients as human capital development strategy that leads to the acquisition of applied and practical skills and basic scientific knowledge required for useful living within the society.

Typically, the aim of TVET is not just to prepare recipients for the world of work, but for further education, and which is why it is so important for citizens of all nations to have access to TVET programme (UNESCO, 2013). Despite the importance of TVET in promoting sustainable development, the rates of unemployment, underemployment, poverty, insecurity and students' dropout is quite alarming, especially in Nigeria. The reasons for the 
alarming rates of these social problems may be that the physical facilities and instructional resources for effective teaching and learning processes in TVET programmes are inadequately provided and rarely utilized, which in turn, affect students' skills acquisition required to confidently pursue entrepreneurial careers and lifelong learning upon graduation (Edokpolor, 2018). Therefore, the implication is that most TVET students are trained under poor learning environment, which reduces their self-efficacy and determination for entrepreneurial careers and lifelong learning.

Based on this situation, the following questions need to be assessed in this study. First, what is the level of physical facilities adequacy for effective teaching and learning in TVET programmes? Second, what is the level of instructional resource utilization for the effective teaching and learning in TVET programmes? Therefore, the study seeks to: (1) determine the level of physical facilities adequacy for teaching and learning effectiveness in TVET programmes; and (2) investigate the level of instructional resources utilization for teaching and learning effectiveness in TVET programmes. The findings of the study are relevant to TVET stakeholders in various ways. Firstly, the findings of the study would help the Ministry of Education in making strategic choices on resource optimization to TVET sector in order to promote teaching and learning delivery. Secondly, the findings of the study would assist TVET administrators and managers from public and private institutions to adopt the right measures that would help optimize available resources for effective teaching and learning processes. Thirdly, the findings of the study would assist researchers in that it would help to establish a literature because of the nonexistent of the topic, thereby, providing a valuable data for researchers with a specific focus on resource adequacy and utilization for teaching and learning effectiveness in TVET programmes in Federal Universities in South-South, Nigeria.

\section{LITERATURE REVIEW}

In the context of this study, resources can be seen as tangible assets that are adequately provided by the school to be used by teachers and students for effective teaching and learning to take place in TVET institutions. Resources have been classified into the physical facilities and instructional resources (Kigwilu \& Akala, 2017). Physical facilities are tangible assets that can easily be seen and observed in TVET institutions. They include entrepreneurship resource centres, staff quarters, workshops, laboratories, equipment, lecture halls, lecture rooms, ICT centres, libraries, health-care centres, hostels, lecturers' offices, sports grounds, structures, et cetera. These physical facilities can contribute directly or indirectly to the teaching and learning processes in TVET institutions. They provide TVET institutions the conducive environment and atmosphere for teaching and learning effectiveness to take place (Abdullahi \& Yusoff, 2017).

Many authors argued that the inadequacy of physical facilities negatively affect teaching and learning processes in TVET institutions (Mupinga, Busby, \& Ngatiah, 2006; Ayuba \& Gatabazi, 2010; Indoshi, Wagah, \& Agak, 2010; Hooker, et al., 2011; Akinfolarin, Ajayi \& Oloruntegbe, 2012; Aworanti, 2015). Osarenren-Osaghae \& Irabor (2012) observed that in most TVET institutions, the state of physical facilities is such that cannot permit the stimulation of effective teaching and learning processes. More so, the utilization of outdated facilities negatively predicts the teaching and learning effectiveness in TVET (UNESCO, 2010). In the study conducted by Kelani (2007), it was found that workshop facilities, such as, hand tools and equipment are not utilized for skill acquisition in TVET institutions. This means that workshops and other physical facilities are inadequately provided in many TVET institutions around the world. Most TVET institutions where there are laboratories

Edokpolor, J. E., \& Dumbiri, D. N. (2019). Resource adequacy and utilization for teaching and learning effectiveness in vocational education programmes in South-South Nigerian Universities. Journal of Vocational Education Studies, 2(1), 1-12. DOI: https://doi.org/10.12928/joves.v2i1.727. 
and workshops, hand tools are not adequately provided, and where available they are inadequate to cope with students' population. From the foregoing, most TVET institutions experience physical facilities inadequacy, which in turn hinders effective teaching and learning, and students' confidence for entrepreneurial careers and lifelong learning.

On the other hand, instructional resources are generally regarded as teaching and learning materials, instructional aids or educational media (Nasibi \& Kiio, 2005). They are tangible assets that are used to facilitate and simplify teaching and learning processes in TVET institutions. The optimal utilization of instructional resources can predict teaching and learning effectiveness. As such, instructional resources utilization in teaching and learning of TVET courses make students learn better and faster and retain better what have been taught and also promote and sustain self-confidence. These instructional resources includes: raw materials, text books, journals and other reading materials. However, the extent of utilization of instructional resources may positively or negatively influence effective teaching and learning in TVET institutions. As such, the effective teaching and learning in TVET institutions can only be possible when instructional resources are always utilized.

The inadequacy of physical facilities can seriously compromise the role of instructional resource utilization in teaching and learning process in TVET programmes. Particularly, lack of modern instructional resources hinders teaching and learning of skill courses (Bandele \& Faremi, 2012). In many developing nations, instructional resources are lacking for successful educating and learning in TVET establishments (Wondaferew, 2012). In Nigeria, for instance, Okwudishu (2005) and Gambari \& Okoli (2007) affirmed that the non-utilization of instructional resources in TVET institutions has hampered teachers teaching and students learning activities. The study conducted by Okolocha \& Nwadiani (2015) have also found that the instructional resources for teaching of vocational business education courses as regards the perception of business education lecturers are rarely used in both colleges of education and universities in South-South, Nigeria.

A review of the literature, as exemplified above, simply reveals that many authors (such as, Yara \& Otieno, 2010; Owoeye \& Yara, 2011; Moochi, 2012; Osarenren-Osaghae \& Irabor, 2012; Oguntuase, Awe \& Ajayi, 2013) have investigated the influence of resource adequacy and utilization on curriculum implementation. However, none of these authors and researchers, nor more current investigations (Chukwunwendu, 2015; Munguti, 2016; Omae, et al., 2016; Chepkonga, 2017; Kigwilu \& Akala, 2017; Ubulom \& Ogwunte, 2017; Dhakal, 2017; Mutindi, 2018) on curriculum implementation specifically assessed the level of resource adequacy and utilization for teaching and learning effectiveness in TVET programmes. Hence, the need for the extant study is informed by the limitations of earlier and more current articles, which suggests a need for further research on resource adequacy and utilization for teaching and learning in TVET programmes.

\section{Research Framework}

The framework of the study is depicted in Figure 1. The research framework is indeed an explicit model that attempted to explain how physical facilities and instructional resources can help to achieve the two major goals of TVET programme. As stipulated in the literature review, physical facilities and instructional resources are required in the teaching and learning procedures to yield the expected instructional outcomes. For instance, instructional resources (such as, textbooks) are helpful in the improvement of instructional content, whereas the physical facilities (such as, laboratories, lecture rooms and workshops) provide supporting environment in which students communicate with the

Edokpolor, J. E., \& Dumbiri, D. N. (2019). Resource adequacy and utilization for teaching and learning effectiveness in vocational education programmes in South-South Nigerian Universities. Journal of Vocational Education Studies, 2(1), 1-12. DOI: https://doi.org/10.12928/joves.v2i1.727. 
content to accomplish the proposed instructional outcomes, such as, lifelong careersspecific skills (Bandele \& Faremi, 2012; Umunadi, 2012; Tshabalala \& Ncube, 2014; Kigwilu \& Akala, 2017).

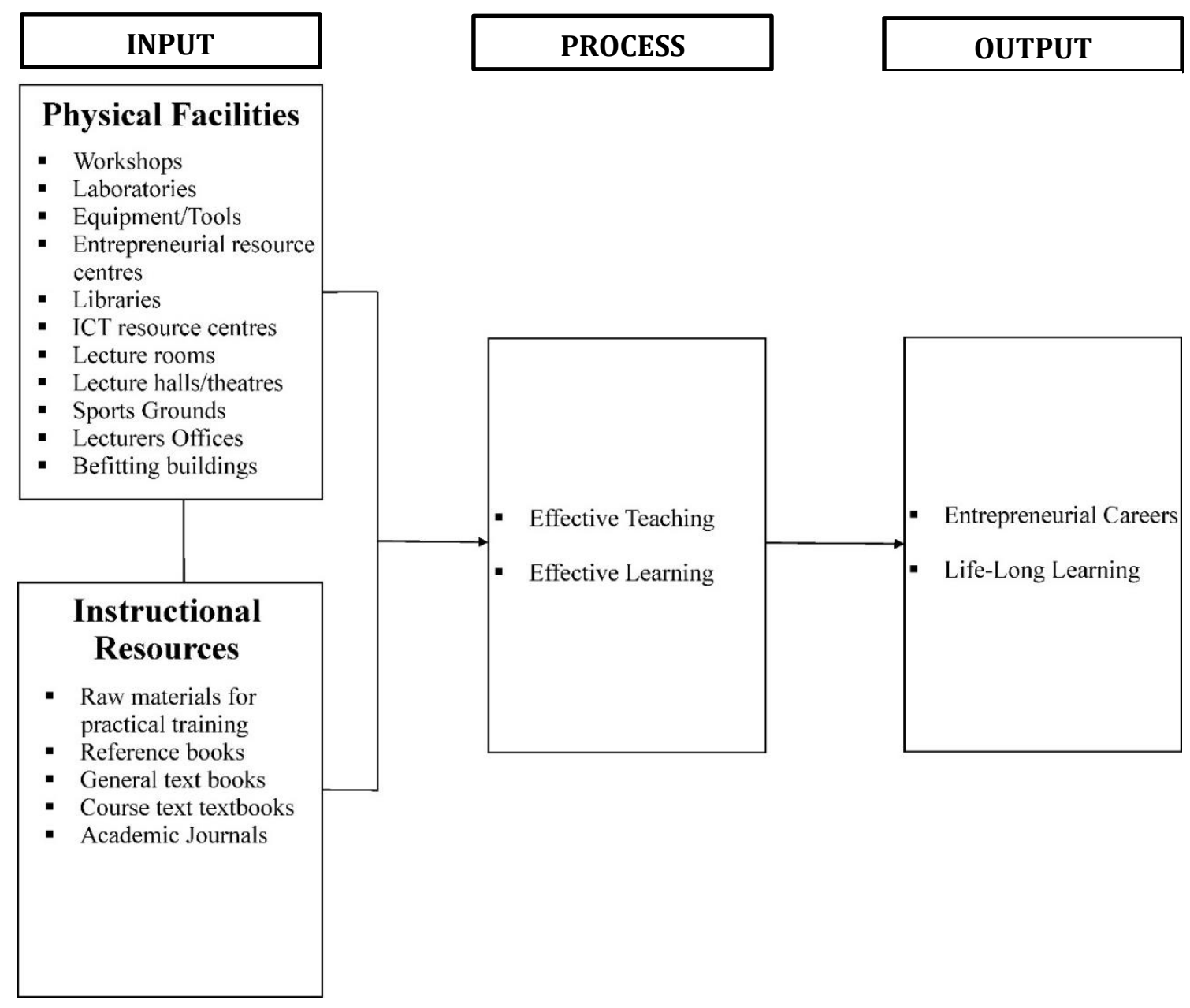

Figure 1. Conceptual model of the study.

The research framework showed three interdependent elements that are responsible for the realization of the goals of TVET. The three elements include: input, process, and output. In the research framework, input is the first element; process is the second element; while output is the third element. The research framework is deliberately adopted for the study so as to illustrate the relationship among inputs, process, and outputs. The inputs that are presented in the research framework are entrepreneurship resource centres, workshops, laboratories, equipment/hand tools, lecture theatres, lecture rooms, ICT resource centres, libraries, lecturers' offices, sports grounds, and befitting structures. The inputs presented in the research framework also include reference books, raw materials for practical training, general textbooks, course textbooks, and academic journals. Both the physical facilities and instructional resources have an important role to play in the effective teaching and learning process in TVET programmes. As such, the conceptual model holds that both physical facilities and instructional resources mutually work together to influence

Edokpolor, J. E., \& Dumbiri, D. N. (2019). Resource adequacy and utilization for teaching and learning effectiveness in vocational education programmes in South-South Nigerian Universities. Journal of Vocational Education Studies, 2(1), 1-12. DOI: https://doi.org/10.12928/joves.v2i1.727. 
effective teaching and learning (Kigwilu \& Akala, 2017). However, once physical facilities are adequately provided and instructional resources are always utilized, the ultimate goals of TVET can be realized, that is producing graduates who will become entrepreneurs and lifelong learners.

\section{RESEARCH METHOD}

This section describes the procedures that were used in conducting the study. These procedures were discussed under the following sub-headings: Research Design, Research Participants, Validity and Reliability of the Instrument, and Method of Data Collection and Analysis.

\section{Research Design}

Quantitative research plan by means of poll was utilized for executing the investigation. This approach was adopted to offer the authors opportunity to have personal interaction with the participants. The study used the questionnaire as an appropriate instrument for the collection of quantitative data (Bryman, 2007).

\section{Research Participants}

The study participants were selected from the Federal Universities in South-South, Nigeria, using simple random sampling technique so that lecturers and students can be adequately represented in the study. A representative sample of 700 participants were utilized in the investigation, which comprised 85 lecturers and 615 undergraduate students who were haphazardly chosen from the Department of Vocational and Technical Education over the three Federal Universities in South-South, Nigeria.

Table 1. Distribution of participants across federal universities in South-South, Nigeria

\begin{tabular}{llcccc}
\hline S/N & Institutions & Lecturers & Students & Total & Percentage (\%) \\
\hline 1. & University of Benin & 24 & 163 & 187 & 27 \\
2. & University of Uyo & 35 & 251 & 286 & 41 \\
3. & University of Calabar & 26 & 201 & 227 & 32 \\
& $\quad$ Total & 85 & 615 & 700 & 100 \\
\hline
\end{tabular}

\section{Validity and Reliability of the Instrument}

Two research instruments were used for data collection. The questionnaires were developed by the authors, primarily for lecturers and students, titled 'Lecturers Questionnaire on Resource Adequacy and Utilization for Effective Teaching and Learning', and 'Students Questionnaire on Resource Adequacy and Utilization for Effective Teaching and Learning'. Each questionnaire was designed as a five-point Likert scale of 16 items, ranging from 5 (Very Adequate) to 1 (Very Inadequate) and 5 (Always) to 1 (Never) for the collection of data. Eleven items measured the level of physical facilities adequacy and five items measured the level of instructional resource utilization. Two lecturers, one from Vocational Education and the other from Measurement and Evaluation, ensured the content validity of the instruments. A reliability test was conducted to determine the internal consistency of the instruments, and the results showed coefficients of $\alpha=0.90$ for lecturers and $\alpha=0.91$ for students through Cronbach's alpha statistic.

Edokpolor, J. E., \& Dumbiri, D. N. (2019). Resource adequacy and utilization for teaching and learning effectiveness in vocational education programmes in South-South Nigerian Universities. Journal of Vocational Education Studies, 2(1), 1-12. DOI: https://doi.org/10.12928/joves.v2i1.727. 


\section{Method of Data Collection and Analysis}

The survey questionnaires were personally administered to the respondents, by the authors with the help of two trained research assistants. To assess the level of physical facilities adequacy and instructional resource utilization for teaching and learning effectiveness in TVET programmes, Mean and standard deviations were used. To assess the differences in lecturers' and students' opinions as regards the level of physical facilities adequacy and instructional resource utilization for teaching and learning effectiveness in TVET programmes, t-test was used.

\section{RESULTS AND DISCUSSION}

\section{Results}

This segment presents and discusses the findings of the investigation dependent on the two research questions raised and the hypotheses formulated for the investigation.

Research Question 1: What is the level of physical facilities adequacy for teaching and learning effectiveness in TVET programmes?

Research Hypothesis 1: There exists no statistically significant difference between the Mean ratings of lecturers and students regarding the level of physical facilities adequacy for teaching and learning effectiveness in TVET programmes.

Table 2. Mean, standard deviations, and t-test results of physical facilities adequacy for teaching and learning effectiveness in TVET programmes by lecturers and students.

\begin{tabular}{|c|c|c|c|c|c|c|c|c|c|c|}
\hline \multirow[b]{3}{*}{$\mathrm{S} / \mathrm{N}$} & \multirow[b]{3}{*}{ Items } & \multicolumn{6}{|c|}{ Physical Facilities Adequacy } & \multirow[b]{3}{*}{ t-value } & \multirow[b]{3}{*}{$\mathrm{p}$-value } & \multirow[b]{3}{*}{ Decision } \\
\hline & & \multicolumn{2}{|c|}{$\begin{array}{l}\text { Lecturers } \\
(\mathrm{n}=85)\end{array}$} & \multicolumn{2}{|c|}{$\begin{array}{l}\text { Students } \\
(\mathrm{n}=615)\end{array}$} & \multicolumn{2}{|c|}{ Total } & & & \\
\hline & & $\mathrm{M}$ & SD & $\mathrm{M}$ & SD & $\mathrm{M}$ & SD & & & \\
\hline 1. & Workshops & 2.34 & .628 & 2.92 & .660 & 2.85 & .682 & 7.561 & .000 & Sig. \\
\hline 2. & Laboratories & 2.42 & .624 & 2.76 & 673 & 2.72 & 676 & 4.347 & .000 & Sig. \\
\hline 3. & Equipment/Hand Tools & 2.39 & .674 & 2.58 & 831 & 2.56 & 815 & 2.042 & .042 & Sig. \\
\hline 4. & $\begin{array}{l}\text { Entrepreneurship } \\
\text { Centres }\end{array}$ & 2.33 & .662 & 2.71 & .748 & 2.66 & .748 & 4.426 & .000 & Sig. \\
\hline 5. & Departmental Libraries & 2.25 & .653 & 2.73 & .723 & 2.67 & .732 & 5.837 & .000 & Sig. \\
\hline 6. & ICT Resource Centres & 2.21 & .514 & 2.66 & .867 & 2.60 & 844 & 4.616 & .000 & Sig. \\
\hline 7. & Lecture Rooms & 2.08 & .727 & 2.65 & 811 & 2.58 & 822 & 6.145 & .000 & Sig. \\
\hline 8. & Lecture Halls/Theatres & 1.26 & .620 & 1.57 & .076 & 1.54 & 036 & 2.640 & .008 & Sig. \\
\hline 9. & $\begin{array}{l}\text { Career Counseling } \\
\text { Centres }\end{array}$ & 2.09 & .629 & 2.38 & .813 & 2.35 & .798 & 3.128 & .002 & Sig. \\
\hline 10. & Lecturers Offices & 1.27 & 625 & 1.59 & 091 & 1.55 & 050 & 2.627 & .009 & Sig. \\
\hline 11. & Structures/Buildings & 2.11 & 618 & 2.36 & .841 & 2.33 & 821 & 2.670 & .008 & Sig. \\
\hline
\end{tabular}

$\mathrm{M}=$ Mean, SD = Standard Deviation, Sig. = Significant.

Results of the data presented in Table 2 shows that the Mean scores imply that physical facilities were not adequately provided for teaching and learning effectiveness in the TVET programmes. Comparatively, each item of the Mean ratings for the students is higher than that of the lecturers on the eleven items of physical facilities adequacy. The pvalues in all the eleven items are not greater than alpha value. This shows that lecturers' and students' ratings of the physical facilities adequacy for effective teaching and learning in the TVET programmes are significantly different in all the eleven physical facilities

Edokpolor, J. E., \& Dumbiri, D. N. (2019). Resource adequacy and utilization for teaching and learning effectiveness in vocational education programmes in South-South Nigerian Universities. Journal of Vocational Education Studies, 2(1), 1-12. DOI: https://doi.org/10.12928/joves.v2i1.727. 
examined in the study. Therefore, hypothesis 1 is not upheld for the eleven items of physical facilities adequacy.

Research Question 2: What is the level of instructional resources utilization for teaching and learning effectiveness in TVET programmes?

Research Hypothesis 2: There exists no statistically significant difference between the Mean ratings of lecturers and students regarding the level of instructional resources utilization for teaching and learning effectiveness in TVET programmes.

Table 3. Mean, standard deviations, and t-test results of instructional resources utilization for teaching and learning effectiveness in TVET programmes by lecturers and students.

\begin{tabular}{|c|c|c|c|c|c|c|c|c|c|c|}
\hline \multirow[b]{3}{*}{$\mathrm{S} / \mathrm{N}$} & \multirow[b]{3}{*}{ Items } & \multicolumn{9}{|c|}{ Instructional Resources Utilization } \\
\hline & & \multicolumn{2}{|c|}{$\begin{array}{c}\text { Lecturers } \\
(\mathrm{n}=85)\end{array}$} & \multicolumn{2}{|c|}{$\begin{array}{l}\text { Students } \\
(\mathrm{n}=615)\end{array}$} & \multicolumn{2}{|c|}{ Total } & \multirow[b]{2}{*}{ t-value } & \multirow[b]{2}{*}{ p-value } & \multirow[b]{2}{*}{ Decision } \\
\hline & & $M$ & $\mathrm{SD}$ & $M$ & SD & $M$ & SD & & & \\
\hline 1. & Raw Materials & 2.35 & .649 & 2.74 & .818 & 2.69 & .809 & 4.280 & .000 & Sig. \\
\hline 2. & Reference Books & 2.26 & .675 & 2.68 & .855 & 2.63 & .846 & 4.321 & .000 & Sig. \\
\hline 3. & General Textbooks & 2.21 & .725 & 2.49 & .925 & 2.45 & .907 & 2.625 & .009 & Sig. \\
\hline 4. & Course Textbooks & 2.25 & .706 & 2.54 & .843 & 2.50 & .833 & 3.038 & .002 & Sig. \\
\hline 5. & Academic Journals & 2.16 & .705 & 2.49 & .915 & 2.45 & .898 & 3.146 & .002 & Sig. \\
\hline
\end{tabular}

$\mathrm{M}=$ Mean, $\mathrm{SD}=$ Standard Deviation, Sig. = Significant.

Results of the data presented in Table 3 shows that the Mean scores imply that the instructional resources were rarely utilized for teaching and learning effectiveness in the TVET programmes. Comparatively, each items of the Mean ratings for the students is higher than that of the lecturers on the five items of instructional resources utilization. The pvalues in the five items are not greater than the alpha value. This shows that lecturers' and students' ratings of the instructional resources utilization for effective teaching and learning in TVET programmes are significantly different in all the five instructional resources assessed in the study. Therefore, hypothesis 2 is not upheld for the five items of instructional resources utilization.

\section{Discussion}

Data from research question 1 reveals that physical facilities are moderately adequate in TVET programmes. This finding corroborates Mbaga, Sambo and Tijjani (2018) finding that physical facilities, such as equipment, hand tools, and machines available in TVET programmes, were not enough to cater for increasing population of students' enrolment. Data from research question also reveals that physical facilities were inadequate for TVET programmes. This finding agrees with the study conducted by Akinfolarin, Ajayi and Oloruntegbe (2012) who found that physical facilities were not adequate for TVET programmes; that physical facilities inadequacy, such as, lecture halls, laboratories, workshops among others can be attributed to insufficiency of funds.

From the test of hypothesis, data reveals that there is significant difference between the Mean ratings of lecturers and students as regards the level of physical facilities adequacy for effective teaching and learning process in TVET programmes. This finding contradicts the study conducted of Kelani (2007) who found that there was no significant difference in Mean ratings of teachers and students as regards physical facilities adequacy in TVET programmes in Lagos and Ogun States. Data from hypothesis 1 do not also support the study conducted by Osarenren-Osaghae and Irabor (2012) who found that there was no

Edokpolor, J. E., \& Dumbiri, D. N. (2019). Resource adequacy and utilization for teaching and learning effectiveness in vocational education programmes in South-South Nigerian Universities. Journal of Vocational Education Studies, 2(1), 1-12. DOI: https://doi.org/10.12928/joves.v2i1.727. 
significant difference in Mean ratings of lecturers and students as regards physical facilities adequacy for effective teaching and learning process in TVET programmes in Nigerian public universities.

Data from research question 2 reveals that instructional resources are moderately utilized for teaching and learning in TVET programmes. Data also reveals that instructional resources were rarely utilized for teaching and learning in TVET programmes. On the contrary, the study conducted by Akinfolarin, Ajayi and Oloruntegbe (2012) shows that most instructional resources were always utilized during teaching and learning in TVET programmes. Although, the finding from research question 1 is in agreement with the study conducted by Indoshi, Wagah, \& Agak (2010) and Mupinga, Busby \& Ngatiah (2006) who found that TVET programmes lack adequate teaching and learning resources, which include textbooks, raw materials and academic journals, and which further hinder effective teaching and learning process. This finding means that TVET lecturers are not always using instructional resources during teaching and learning in TVET programmes.

From the test of hypothesis, data reveals that there was significant difference between the Mean ratings of lecturers and students as regards the level of instructional resources utilization for effective teaching and learning in TVET programmes. This finding contradicts the findings of Kelani (2007) who found that there was no significant difference in Mean ratings of teachers and students as regards the use of instructional resources in TVET programmes in Lagos and Ogun States. Furthermore, the finding from hypothesis 2 does not support the findings of Ogbu (2015) who found that there was no significant difference in the Mean ratings of lecturers and students on the use of instructional resources for effective teaching and learning in TVET programmes in Ebonyi State.

\section{CONCLUSION}

The data gathered from this study has indicated inadequate provision of physical facilities and rare utilization of instructional resources for teaching and learning of TVET courses. The data also indicates significant difference between the Mean ratings of lecturers and students regarding the level of physical facilities adequacy and instructional resources utilization for teaching and learning effectiveness in TVET programmes. Thus, the authors conclude that the inadequacy of physical facilities and rare use of instructional resources could be responsible for the ineffective teaching and learning process in TVET programmes. This situation could be responsible for the low level of self-efficacy by TVET students to engage in entrepreneurial career and lifelong learning tasks. The authors also summit that there is a discrepancy between the lecturers' and students' of TVET with respect to the level of physical facilities adequacy and instructional resources utilization for teaching and learning effectiveness in TVET programmes.

Based on the findings of the study and conclusions arising therefrom, it is recommended that first, TVET managers should endeavour to collaborate with other major stakeholders for the provision of funds to ensure adequate provision of physical facilities for teaching and learning effectiveness in TVET programmes. Ensuring adequate provision of physical facilities will help in guaranteeing conducive learning environment for TVET students. Second, TVET managers should endeavour to collaborate with other major stakeholders for the provision of funds that can help to ensure the provision of instructional resources so that lecturers can utilize them for the effective teaching and learning of TVET courses. This should equip students with requisite skills to engage in entrepreneurial career and lifelong learning tasks upon graduation.

Edokpolor, J. E., \& Dumbiri, D. N. (2019). Resource adequacy and utilization for teaching and learning effectiveness in vocational education programmes in South-South Nigerian Universities. Journal of Vocational Education Studies, 2(1), 1-12. DOI: https://doi.org/10.12928/joves.v2i1.727. 


\section{REFERENCES}

Abdullahi, I. \& Yusoff, W. Z. W. (2018). Effect of the performance of physical and nonphysical facilities on higher institutional facilities. Journal of Facilities Management, 113.

Akinfolarin, C. A., Ajayi, I. A., \& Oloruntegbe, K. O. (2012). An Appraisal of Resource Utilization in Vocational and Technical Education in Selected Colleges of Education in Southwest Nigeria. Education, 2(1), 41-45.

Ayuba, U., \& Gatabazi, P. (2010). The role of technical and vocational education and training (TVET) in human resources development: The case of Tumba College of Technology (TCT). Rwanda: Tumba College of Technology.

Aworanti, O. A. (2015). Partnership in technical and vocational education and training (TVET) for national development. A Lead Paper Presented at the 23rd Annual International Conference of the Nigerian Vocational Association, Held at Yaba College of Technology, Lagos. From 5th - 8th August, 2015.

Bandele, S., \& Faremi, Y. (2012). An investigation into the challenges facing the implementation of technical college curriculum in South West, Nigeria. Journal of Education and Practice, 3(12), 8-13.

Bryman, A. (2007). Qualitative data analysis. London: SAGE Publications.

Chepkonga, M. C. (2017). Influence of learning facilities on provision of quality education in early childhood development centres in Kenya. International Journal of Education and Research, 5(6), 15-26.

Chukwunwendu, A. F. (2015). New dimensions in sourcing and utilization of resource materials for effective teaching and instruction in technical vocational education and training (TVET) in Nigeria. Education Journal, 4, 24-30.

Cohen L., Manion L, \& Morrison K. (2007). Research methods in education. New York: Routledge.

Dhakal, K. R. (2017). Availability and utilization of instructional materials in teaching geography in secondary schools. Journal of Geography, 17, 51-58

Edokpolor, E. J. (2018). Systems approach in developing creative thinking and innovative capabilities for lifelong learning among TVET students in Federal Universities, SouthSouth, Nigeria. International Journal of Educational Development (IJED), 21(1), 1-15.

FRN. (2004). National Policy on Education. Lagos: NERDC Press, Federal Republic of Nigeria.

FRN. (2017). Nigeria sustainable development goals (SDGs) indicators baseline report 2016. Federal Republic of Nigeria.

Gambari, A. I. \& Okoli, A. (2007). Availability and utilization of information and communication technology (ICT) facilities in higher institutions in Niger State, Nigeria. Information Technology, 4, 34-46.

Hooker, E., Mwiyeria, S., Waweru, M., Ocharo, R., Bassi, L., Palmer, D., \& Clark, D. (2011). TIVET ICT baseline survey report 2011: TIVET institutions, Kenya. Retrieved from http://scholar.lib.vt.edu.ezproxy.waikato.ac.nz.

Ibukun, W. O., Akinfolarin, C. A., \& Alimi, O. S. (2011). Correlate of Resource Utilization and Students' Learning Outcome in Colleges of Education in South West Nigeria. International Education Studies, 4(3), 178-184.

Edokpolor, J. E., \& Dumbiri, D. N. (2019). Resource adequacy and utilization for teaching and learning effectiveness in vocational education programmes in South-South Nigerian Universities. Journal of Vocational Education Studies, 2(1), 1-12. DOI: https://doi.org/10.12928/joves.v2i1.727. 
Indoshi, C., Wagah, O., \& Agak, O. (2010). Factors that determine students' and teachers' attitudes towards Art and Design curriculum. International Journal of Vocational and Technical Education, 2(1), 9-17.

Kelani, R. A. (2007). Assessment of the adequacy and utilization of woodwork equipment for acquisition in technical colleges in Lagos and Ogun States. Master's Thesis. Nsukka: University of Nigeria.

Kigwilu, P. C., \& Akala, W. J. (2017). Resource utilization and curriculum implementation in community colleges in Kenya. International Journal for Research in Vocational Education and Training, 4(4), 369-381.

Mbaga, E. V., Sambo, M. M., \& Tijjani, A. (2018). Adequacy of workshop facilities in colleges of education (technical) for training of trade teachers of technical colleges in North Eastern States of Nigeria. International Journal of Vocational and Technical Education Research, 4(1), 42-49.

Moochi, 0. (2012). Availability, acquisition and Utilization of instructional resources for teaching Geography in selected secondary schools in Central Kisii District. Master's Thesis. Nairobi: Kenyatta University

Munguti, S. (2016). Learning resources and students' academic performance in geography in Makueni County, Kenya. Thesis. Nairobi, Kenyatta University.

Mupinga, M., Busby, R., \& Ngatiah, W. (2006). Postsecondary technical and vocational education institutions in Kenya: Needs and challenges. International Journal of Vocational Education and Training, 14(1), 21-35.

Mutindi, M. J. (2018). School based factors influencing students' performance in Kenya certificate of secondary examination in public secondary schools in Kathiani SubCounty. Thesis. Nairobi: South Eastern Kenya University.

Nasibi, W. \& Kiio, M. (2005). History and government handbook for teachers. Nehema Publishers Nairobi.

Ogbu, J. E. (2015). Availability and utilization of instructional facilities for the teaching of basic electricity in Ebonyi State technical colleges. Developing Country Studies, 5(21), 162-168.

Oguntuase, D. M., Awe, O. O., \& Ajayi, I. A. (2013). Empirical nexus between teaching/learning resources and academic performance in mathematics among preuniversity students in Ile-Ife, South-West Nigeria. International Journal of Scientific and Research Publications, 3(3), 1-6.

Okolocha, C. C., \& Nwadiani, C. O. (2015). Assessment of utilization of ICT resources in teaching among tertiary institution business educators in South Nigeria. Journal of Education and Learning, 4(1), 1-10.

Okwudishu, C. H. (2005). Awareness and use of information and communication technology and secondary schools: First results from the ICTs in school survey, 2003-2004. Retrieved from http://www.stacan.ca/English/research/81-595.MIE 2004 07.pdf

Omae, D. O., Onderi, P. O., Mokogi, H. M., Bantu, E., Barongo, S., Miroro, R. S., \& Evans, M. N. (2016). Factors affecting the utilization of time as a selected teaching/learning resource in public day secondary schools in Nyacheki Division, Kisii County, Kenya. American Journal of Education and Learning, 1(1), 16-24.

Edokpolor, J. E., \& Dumbiri, D. N. (2019). Resource adequacy and utilization for teaching and learning effectiveness in vocational education programmes in South-South Nigerian Universities. Journal of Vocational Education Studies, 2(1), 1-12. DOI: https://doi.org/10.12928/joves.v2i1.727. 
Osarenren-Osaghae, R. I., \& Irabor, Q. O. (2012). Availability and adequacy of human and material resources for the teaching and learning of skill-based courses in Nigeria public universities. Journal of Sociology and Social Anthropology, 3(1), 15-27.

Owoeye, J. S. \& Yara, P. O. (2011). School facilities and academic achievement of secondary school agricultural science in Ekiti State, Nigeria. Asian Social Science, 7(7), 64-74.

Tshabalala, T., \& Ncube, C. (2014). Teachers' perceptions on challenges faced by rural secondary schools in the implementation of the technical and vocational education and training policy in Nkayi District. International Research Journal of Teacher Education, 1(2), 10-15.

Ubulom, W. J., \& Ogwunte, P. C. (2017). Evaluation of instructional resources for teaching business subjects in public secondary schools in Rivers State, Nigeria. International Journal of Innovative Education Research, 5(4), 67-74.

Umunadi, K. (2012). Resource management and planning in vocational and technical education for national development: An assessment. African Journal of Educational Technology, 2(1), 48-59.

UNESCO. (2010). Reaching the marginalized: EFA global monitoring report 2010. Paris and London: UNESCO Publishing and Oxford University Press.

UNESCO. (2013). Shanghai Update, Issue No. 1, June 2013. Bonn: UNESCO-UNEVOC.

UN. (2017). The sustainable development goals report. New York: United Nations.

Yara, P. \& Otieno, K. (2010). Teaching/learning instructional resources and academic performance in mathematics in secondary schools in Bondo District of Kenya. Asian Social Science, 6(12), 126-132.

Wondaferew, A. (2012). Factors influencing the quality of training: Technical and vocational education in Addis Ababa. Korea Review of International Studies, 15(1), 49-63.

Edokpolor, J. E., \& Dumbiri, D. N. (2019). Resource adequacy and utilization for teaching and learning effectiveness in vocational education programmes in South-South Nigerian Universities. Journal of Vocational Education Studies, 2(1), 1-12. DOI: https://doi.org/10.12928/joves.v2i1.727. 
Edokpolor, J. E., \& Dumbiri, D. N. (2019). Resource adequacy and utilization for teaching and learning effectiveness in vocational education programmes in South-South Nigerian Universities. Journal of Vocational Education Studies, 2(1), 1-12. DOI: https://doi.org/10.12928/joves.v2i1.727. 